Sains Malaysiana 47(8)(2018): 1693-1700

http://dx.doi.org/10.17576/jsm-2018-4708-08

\title{
Responses of Four Citrus Plants to Phytophthora-Induced Root Rot
}

(Tindak Balas Empat Tumbuhan Sitrus kepada Reput Akar Diinduksi dengan Phytophthora)

\section{Li Tian, QIANG-SHENG WU*, KAMIL KuČA \& MOHAMmED MAHABUBUR RAHMAN}

\section{ABSTRACT}

China is one of the largest citrus producers in Asia, where Phytophthora parasitica infection has become the major threat in sustaining long term citrus production. The proposed study examined the effects of P. parasitica on Citrus junos, C. limon, C. tangerina and Poncirus trifoliata to evaluate the resisted rootstock to Phytophthora root rot. P. parasitica infection notably decreased plant growth, root morphology and activities of pathogenesis-related proteins (PRS) in C. limon and C. tangerina. Root $\beta$-1,3-glucanase, chitinase and phenylalanine ammonialyase activities significantly increased in $\mathrm{C}$. junos and P. trifoliata after infection with P. parasitica. P. parasitica infection notably decreased root salicylic acid concentrations in $\mathrm{C}$. limon, C. tangerina and $\mathrm{P}$. trifoliata, while increasing it in $\mathrm{C}$. junos. An opposite trend was observed in root jasmonic acid levels after infection with $\mathrm{P}$. parasitica, relative to root salicylic acid. Root nitric oxide and calmodulin concentrations were significantly increased in P. parasitica-infected C. junos, C. tangerina and $\mathrm{P}$. trifoliata, while $\mathrm{C}$. limon exhibited a decrease. These results demonstrated that citrus species like $\mathrm{C}$. junos and $\mathrm{P}$. trifoliata displayed a much higher resistance to Phytophthora-induced root rot, and $\mathrm{C}$. limon and $\mathrm{C}$. tangerina showed a comparatively lower degree of resistance.

Keywords: Citrus junos; pathogenesis-related protein; Phytophthora parasitica; Poncirus trifoliata

\section{ABSTRAK}

Negara China ialah salah sebuah negara pengeluar sitrus terbesar di Asia dengan jangkitan Phytophthora parasitica telah menjadi ancaman utama dalam mengekalkan pengeluaran sitrus berjangka panjang. Kajian yang dicadangkan untuk mengkaji kesan P. parasitica pada Citrus junos, C. limon, C. tangerina dan Poncirus trifoliata bagi menilai akar umbi yang ditentang terhadap reput akar Phytophthora. Jangkitan P. parasitica terutamanya menurunkan pertumbuhan tumbuhan, morfologi akar dan aktiviti protein yang berkaitan patogenesis (PR) pada C. limon dan C. tangerina. Akar 3-1,3-glukanase, kitinase and fenilalanina ammonia-liase meningkat dengan ketara pada C. junos dan P. trifoliata selepas jangkitan P. parasitica. P. parasitica terutamanya menurunkan kepekatan asid salisilik akar dalam C. limon, C. tangerina dan P. trifoliata manakala meningkatkannya dalam C. junos. Tren yang bertentangan telah diperhatikan pada peringkat asid jasmonik akar selepas jangkitan dengan P. parasitica berbanding dengan asid salisilat akar. Kepekatan nitrik oksida dan kalmodulin akar meningkat dengan ketara pada P. parasitica yang dijangkiti C. junos, C. tangerina dan P. trifoliata manakala C. limon menunjukkan suatu penurunan. Keputusan ini menunjukkan bahawa spesies sitrus seperti C. junos dan $\mathrm{P}$. trifoliata menunjukkan rintangan yang lebih tinggi terhadap reput akar diinduksi dengan Phytophthora serta $\mathrm{C}$. limon dan C. tangerina menunjukkan tahap rintangan yang agak rendah.

Kata kunci: Citrus junos; Phytophthora parasitica; Poncirus trifoliata; protein yang berkaitan patogenesis

\section{INTRODUCTION}

Citrus is one of the important economic crops in the world, which is susceptible to a large number of diseases. Phytophthora-induced root rot is one of the most serious and destructive citrus diseases, considered to be the main obstacle towards stable high yield of citrus (Yan et al. 2017). In the early stage of root rot infection, the infection site presents irregularly wet and rot, resulting in xylem decay with pathogen extension (Yan et al. 2017).

The predominant pathogen of citrus root rot was identified as Phytophthora spp., primarily including $P$. cactorum, P. capsici, P. citrophthora, P. palmvora and $P$. parasitica (Zhou 1999), among which P. parasitica was reported as the main pathogen of citrus root rot in China (Liu et al. 1993; Zhou 1999). Infected trees usually lose vigor and may die prematurely (Queiroz et al. 2006). The soil-borne pathogen causes a multicyclic disease, living on both dead (as necrotrophic) and live (as biotrophic) plant organs and reproducing both sexually and asexually (Bonnet et al. 2007). The current practices for controlling Phytophthora diseases are largely based on improved cultivation practices in fields and application of synthetic fungicides (metalaxyl and fosetyl AI) (Gray et al. 2017; Latijnhouwers et al. 2003). However, long term application of chemical pesticides for the control of plant pathogens can trigger threatening levels of toxins in the 
environment and adverse effects on human health. Hence, it is particularly crucial to find the citrus rootstock against Phytophthora-induced root rot.

The present work was made to infect $P$. parasitica into four citrus genotype plants to identify a resistant citrus rootstock against Phytophthora-induced root rot by comparing plant growth performance, root morphology, activities of pathogenesis-related proteins (PRs) and signal substance concentrations.

\section{MATERIALS AND METHODS}

\section{EXPERIMENTAL DESIGN}

The experiment was carried out in a completely randomized design with eight treatments: orange (Citrus junos Sieb. ex Tanaka) without $P$. parasitica infection $(C . j-P . p)$, orange with $P$. parasitica infection $(C . j+P . p)$, lemon [Citrus limon (L.) Burm. F.] without P. parasitica infection (C. l-P.p), lemon with $P$. parasitica infection $(C . l+P . p)$, tangerine (Citrus tangerina Hort. ex Tanaka) without $P$. parasitica infection (C. t-P.p), tangerine with $P$. parasitica infection (C. $t+P . p)$, trifoliate orange [Poncirus trifoliata (L.) Raf.] without $P$. parasitica infection $(P . t-P . p)$ and trifoliate orange with $P$. parasitica infection $(P . t+P . p)$. The four citrus plants are major rootstocks used for commercial cultivation of Satsuma mandarin in China. Each treatment was replicated five times, with a total of 40 pots, and one citrus seedling per pot.

\section{PLANT CULTURE}

Seeds of $C$. junos, $C$. limon, $C$. tangerina and $P$. trifoliata were sterilized with $70 \%$ alcohol solution for $10 \mathrm{~min}$ and then germinated on autoclaved $\left(0.11 \mathrm{MPa}, 121^{\circ} \mathrm{C}\right.$, $2 \mathrm{~h}$ ) sands under the conditions of $28 / 20^{\circ} \mathrm{C}$ day/night temperature and $80 \%$ relative air humidity. Subsequently, one 3-leaf-old seedling with uniform size was transplanted into the plastic pot $(13.5 \mathrm{~cm}$ upper diameter $\times 9.5 \mathrm{~cm}$ height $\times 11 \mathrm{~cm}$ bottom diameter), supplied with $1.5 \mathrm{~kg}$ of autoclaved $\left(0.11 \mathrm{MPa}, 121^{\circ} \mathrm{C}, 2 \mathrm{~h}\right)$ substrates (soil : sand $=5: 1, \mathrm{v} / \mathrm{v})$. All these pots were placed in a plastic greenhouse of Yangtze University campus. The growing conditions of greenhouse were characterized by photon flux density of $721-967 \mu \mathrm{mol} / \mathrm{m}^{2} / \mathrm{s}$ with $25 / 19^{\circ} \mathrm{C}$ average day/night temperature and $75-95 \%$ relative air humidity.

\section{PATHOGEN INFECTION}

$P$. parasitica was freely provided by the Citrus Research Institute, Chinese Academy of Agricultural Sciences. $P$. parasitica was grown in PDA medium at $28^{\circ} \mathrm{C}$ for 7 days for the pathogen infection. After 8 weeks of transplanting, the sclertium of $P$. parasitica $(5 \times 5 \mathrm{~mm})$ was applied on the root neck of four citrus plants according to the protocol proposed by Zhou (1999).

\section{OBSERVATIONS AND ANALYTICAL METHODS}

A week later of the pathogen infection, all the citrus plants were harvested and divided into shoots and roots, whose fresh weight was measured. Height, stem diameter and leaf number were measured before plant was harvested. The root system of each plant was scanned by the Epson Perfection V700 Photo Dual Lens System (J221 A, Indonesia). Root morphological traits, including length, diameter, projected area, surface area and volume were analyzed with the scanned photo by a WinRHIZO professional software in 2007b (Regent Instruments Inc., Quebec, Canada).

Root $\beta$-1,3-glucanase activity was determined by the method of $\mathrm{Hu}$ et al. (2017). An enzyme activity unit was defined as enzyme amounts required for catalyzing laminarin and releasing $1 \mu \mathrm{g}$ glucose by $1 \mathrm{~g}$ of fresh tissue per minute in certain conditions $\left(37^{\circ} \mathrm{C}, \mathrm{pH} 5.0\right)$.

Root chitinase activity was measured according to the method of $\mathrm{Hu}$ et al. (2017). An enzyme activity unit was defined as enzyme amounts required for catalyzing colloidal chitin and releasing $1 \mu \mathrm{mol} \mathrm{N}$-acetylglucosamine (NAG) by $1 \mathrm{~g}$ of fresh tissue per minute in certain conditions $\left(37^{\circ} \mathrm{C}, \mathrm{pH} 5.0\right)$.

Root phenylalanine ammonia-lyase (PAL) activity was assayed using the method of Kofalvi and Nassuth (1995), where an enzyme activity unit was defined as enzyme amounts required for optical density (OD) change of 0.01 unit per hour at $290 \mathrm{~nm}$.

Root salicylic acid (SA), jasmonic acid (JA), nitric oxide (NO) and calmodulin ( $\mathrm{CaM}$ ) concentrations were assayed by double antibody sandwich-elisa kits in ELISA as per the user handbook (Shanghai Enzyme Linked Biotechnology Co., Ltd, China).

\section{STATISTICAL ANALYSIS}

Data (means $\pm \mathrm{SD}, n=8$ ) were analyzed with ANOVA (SAS, version 8.1) and the significant differences among these treatments were compared with the Fisher's Protected Least Significant Difference (LSD) at $p<0.05$.

\section{RESULTS}

\section{PLANT GROWTH PERFORMANCE}

Treatment with $P$. parasitica significantly reduced the growth performance of different citrus plants, as compared with non-infected treatment (Table 1). P. parasitica infection dramatically decreased plant height, stem diameter, leaf number, shoot biomass and root biomass by $4 \%, 12 \%, 11 \%, 9 \%$ and $14 \%$ in C. tangerina and by $9 \%, 8 \%, 13 \%, 20 \%$ and $21 \%$ in C. limon, respectively. In $C$. junos and P. trifoliata, plant height, stem diameter, shoot biomass and root biomass significantly reduced by $3 \%, 3 \%, 9 \%$ and $15 \%$ under $P$. parasitica condition and by $4 \%, 2 \%, 9 \%$ and $14 \%$ under $P$. parasitica condition, respectively. Leaf number was not significantly affected by the pathogen infection. 
TABLE 1. Effects of Phytophthora parasitica infection on plant growth of Citrus junos, C. limon,

C. tangerina and Poncirus trifoliata seedlings

\begin{tabular}{lcccccc}
\hline Citrus plants & $\begin{array}{c}\text { Phytophthora } \\
\text { parasitica } \\
\text { treatments }\end{array}$ & $\begin{array}{c}\text { Plant height } \\
(\mathrm{cm})\end{array}$ & $\begin{array}{c}\text { Stem diameter } \\
(\mathrm{mm})\end{array}$ & $\begin{array}{c}\text { Leaf number } \\
\text { per plant }\end{array}$ & $\begin{array}{c}\text { Shoot biomass } \\
(\mathrm{g} \mathrm{DW} / \mathrm{plant})\end{array}$ & $\begin{array}{c}\text { Root biomass } \\
(\mathrm{g} D W / \mathrm{plant})\end{array}$ \\
\hline Citrus junos & $-P . p$ & $10.71 \pm 0.49 \mathrm{c}$ & $1.94 \pm 0.11 \mathrm{~cd}$ & $11 \pm 0.69 \mathrm{~b}$ & $1.13 \pm 0.01 \mathrm{a}$ & $0.33 \pm 0.03 \mathrm{c}$ \\
& $+P . p$ & $9.36 \pm 0.69 \mathrm{~d}$ & $1.88 \pm 0.11 \mathrm{~d}$ & $11 \pm 0.69 \mathrm{~b}$ & $0.87 \pm 0.07 \mathrm{~cd}$ & $0.28 \pm 0.03 \mathrm{~d}$ \\
C. limon & $-P . p$ & $9.36 \pm 0.56 \mathrm{~d}$ & $1.71 \pm 0.13 \mathrm{e}$ & $8 \pm 0.82 \mathrm{~d}$ & $0.54 \pm 0.03 \mathrm{e}$ & $0.34 \pm 0.03 \mathrm{c}$ \\
& $+P . p$ & $8.43 \pm 0.61 \mathrm{e}$ & $1.58 \pm 0.07 \mathrm{f}$ & $7 \pm 0.69 \mathrm{~d}$ & $0.53 \pm 0.05 \mathrm{e}$ & $0.27 \pm 0.02 \mathrm{~d}$ \\
C. tangerina & $-P . p$ & $9.57 \pm 0.35 \mathrm{~d}$ & $2.21 \pm 0.12 \mathrm{a}$ & $9 \pm 0.69 \mathrm{c}$ & $0.94 \pm 0.08 \mathrm{bc}$ & $0.63 \pm 0.04 \mathrm{a}$ \\
& $+P . p$ & $9.14 \pm 0.24 \mathrm{ed}$ & $1.94 \pm 0.15 \mathrm{bcd}$ & $8 \pm 0.53 \mathrm{~cd}$ & $0.85 \pm 0.04 \mathrm{~d}$ & $0.54 \pm 0.03 \mathrm{~b}$ \\
Poncirus trifoliata & $-P . p$ & $18.54 \pm 0.99 \mathrm{a}$ & $2.07 \pm 0.16 \mathrm{~b}$ & $15 \pm 1.27 \mathrm{a}$ & $0.96 \pm 0.05 \mathrm{~b}$ & $0.66 \pm 0.03 \mathrm{a}$ \\
& $+P . p$ & $17.75 \pm 1.01 \mathrm{~b}$ & $2.03 \pm 0.16 \mathrm{bc}$ & $15 \pm 1.15 \mathrm{a}$ & $0.87 \pm 0.08 \mathrm{~cd}$ & $0.57 \pm 0.04 \mathrm{~b}$ \\
\hline
\end{tabular}

Data (means $\pm \mathrm{SD}, n=8)$ followed by different letters in a row indicate significant differences $(p<0.05)$ between treatments. Abbreviation: - P. p, non-infection by Phytophthora parasitica; $+P . p$, infection by Phytophthora parasitica

\section{ROOT MORPHOLOGY}

Compared with non-infected treatment, infection with $P$. parasitica prominently showed a reduction in root total length, projected area and surface area by $4 \%, 12 \%$ and $4 \%$ in C. tangerina , 34\%, $24 \%$ and $24 \%$ in C. limon and $8 \%, 9 \%$, and $10 \%$ in P. trifoliata, respectively (Table 2). $C$. junos had no significant response to infection with $P$. parasitica with regard to root total length, projected area and volume. Furthermore, compared with non-infected treatment, $P$. parasitica infection dramatically decreased the number of 1 st- and 2 nd- order lateral roots (LRs) by $6 \%$ and $22 \%$ in C.tangerina, by $6 \%$ and $63 \%$ in C. limon and by $11 \%$ and $36 \%$ in P. trifoliata (Table 2). There were no changes in the 3 rd-order LR in C. tangerina, C. limon and $C$. junos, except for $P$. trifoliata, relative to non-infected seedlings.

\section{ACTIVITIES OF ROOT PATHOGENESIS-RELATED PROTEINS}

The pathogen infection distinctively increased root $\beta-1,3-$ glucanase activities as compared with the non-infected treatment, registering as much as $19 \%$ higher activity in $C$. junos and $17 \%$ higher in P. trifoliata, respectively (Figure 1(a)). However, in comparison with non-infected treatment, root $\beta$-1,3-glucanase activities decreased evidently by $16 \%$ and $13 \%$ under the condition of P. parasitica in C.limon and $C$. tangerina, respectively.

In comparison with non-infected treatments, root chitinase activities decreased prominently by $13 \%$ and $22 \%$ in $C$. tangerina and $C$. limon when infected with $P$. parasitica (Figure 1(b)). Besides, $P$. parasitica infection prominently increased root chitinase activities by $22 \%$ and $5 \%$ in C. junos and P. trifoliata, respectively, as compared with non-infected seedlings.

Compared with non-infected treatment, $P$. parasitica infection significantly reduced root PAL activities by $45 \%$ in C. tangerina and $9 \%$ in C. limon, respectively (Figure 1(c)). Besides, the pathogen infection dramatically promoted root PAL activities by $67 \%$ in C. junos and by $56 \%$ in P. trifoliata, respectively, as compared with non-infected treatment.

\section{CONCENTRATIONS OF ROOT SIGNAL SUBSTANCES}

$P$. parasitica infection dramatically decreased root SA concentrations by $30 \%$ in C. tangerina and $26 \%$ in $C$. limon, respectively, in contrast with non-infected seedlings (Figure 2(a)). There were no significant differences in root SA contents between infected and non-infected $P$. trifoliata. Moreover, root SA concentrations prominently increased by $10 \%$ in infected C. junos in comparison with non-infected seedlings.

Compared with non-infected treatment, $P$. parasitica infection dramatically elevated root JA concentrations: $32 \%$ higher in C. tangerina, $35 \%$ in C. limon and $34 \%$ in P. trifoliata (Figure 2(b)).

Root NO contents were decreased by $5 \%$ in infected $C$. limon, as compared with non-infected $C$.limon (Figure 2(c)). Additionally, $P$. parasitica infection evidently improved root NO concentrations by $5 \%$ in $C$. tangerina, $31 \%$ in C. junos and $21 \%$ in P. trifoliata, respectively, as compared with non-infected seedlings.

In comparison with non-infected treatment, $P$. parasitica infection notably increased root $\mathrm{CaM}$ concentrations: $55 \%$ higher in $C$. tangerina, $41 \%$ in $C$. junos and $12 \%$ in P. trifoliata, respectively (Figure 2(d)). Root CaM contents in P.parasitica-infected $C$. limon were dramatically reduced by $24 \%$ in relation to non-infected plants.

\section{DISCUSSION}

In this study, plant height, stem diameter, shoot biomass and root biomass of four citrus plants infected with $P$. parasitica were significantly lower than those non-infected with P.parasitica. This is in accordance with earlier results conducted by Davis and Menge (1980), who reported that sole $P$. parasitica infection dramatically decreased plant growth performance than non-infected sweet orange. This manifested that $P$. parasitica infection had the negative effect on plant growth traits of citrus plants. Moreover, taking the relative reduction of plant growth indexes into 


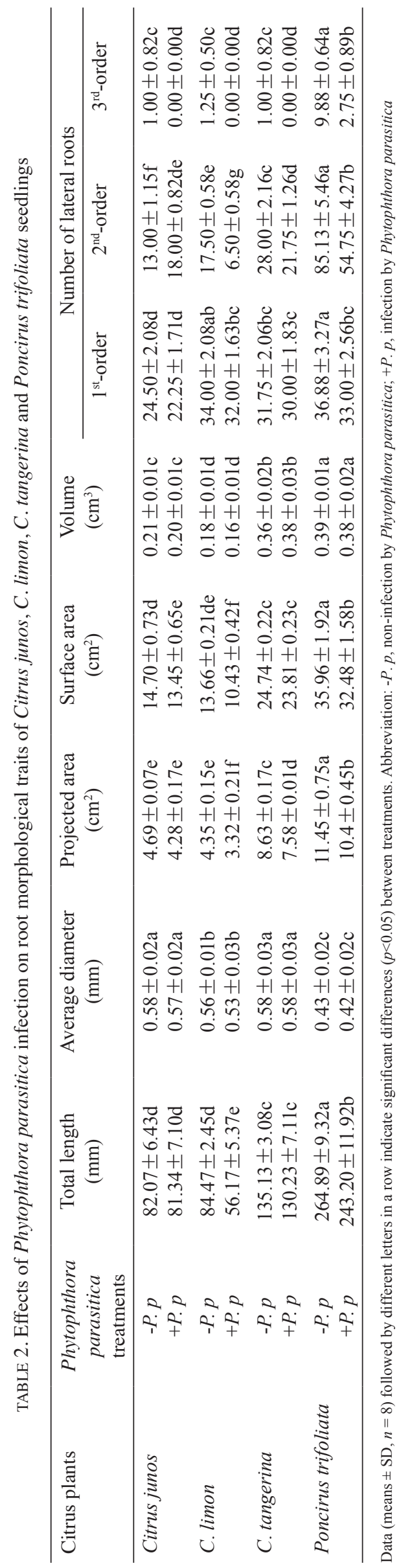




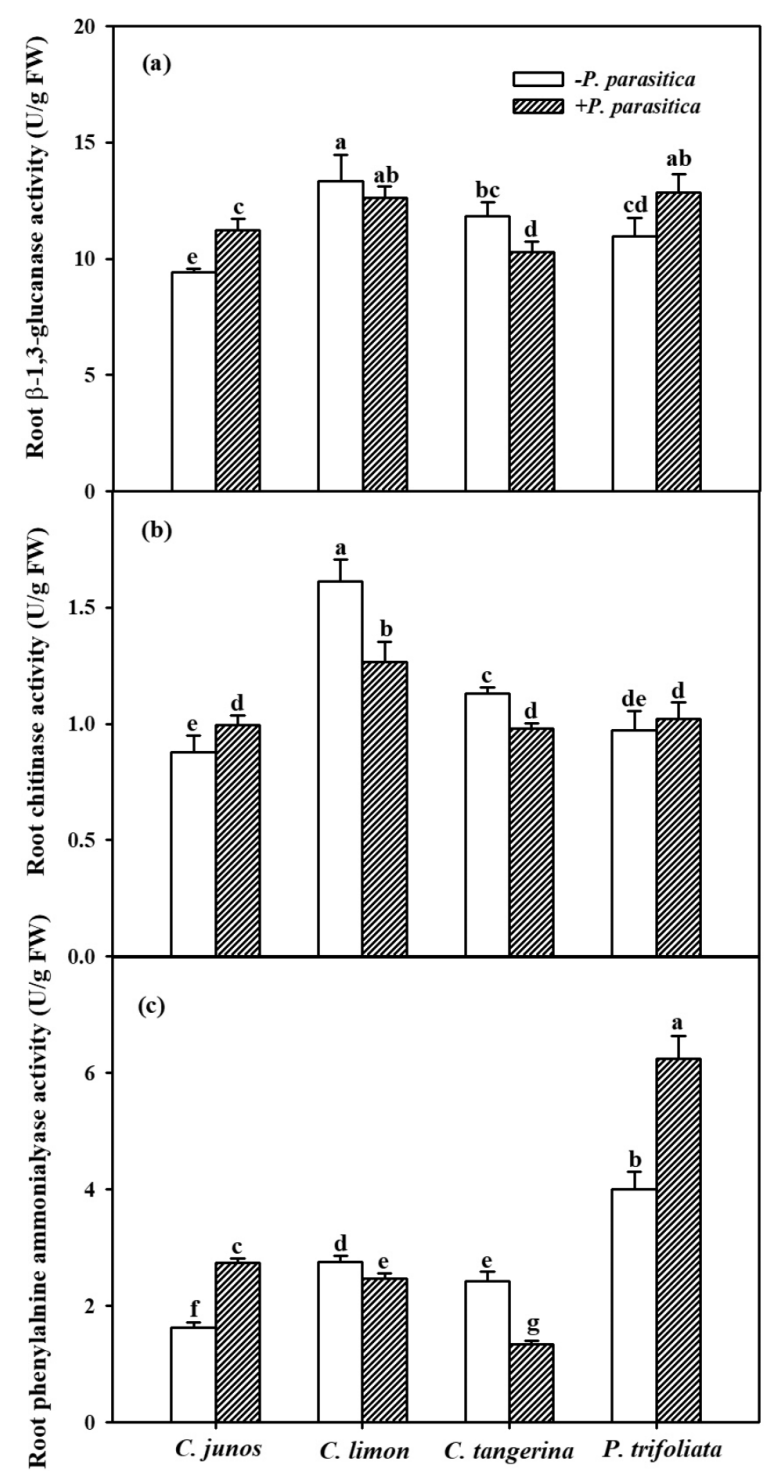

FIGURE 1. Effects of Phytophthora parasitica infection on root $\beta-1,3$-glucanase (a), chitinase (b) and phenylalnine ammonialyase (c) activities in Citrus junos, C. limon, C. tangerine and Poncirus trifoliata. Data (means \pm SD, $n$ $=8)$ are significantly different $(p<0.05)$ followed by different letters above the bars. Abbreviation: $-P$. parasitica, non-infection by Phytophthora parasitica; $+P$. parasitica, infection by Phytophthora parasitica

consideration, $C$. junos and $P$. trifoliata performed better than $C$. tangerina and $C$. limon, suggesting that $C$. junos and P. trifoliata had higher resistance to Phytophthora root rot than the other two citrus plants.

In the present study, $P$. parasitica infection notably reduced root morphological traits of citrus plants than those of non-inoculated plants, apart from $C$. junos, whose root morphological traits were less affected by $P$. parasitica. This suggested that $C$. junos presented high tolerance to root rot by $P$. parasitica. Besides, the number of LRs in $P$. parasitica-infected plants was evidently lower than in non-infected plants, except for the 2nd-order LRs in C. junos. As reported by Vallad (2004), plant protected themselves from pathogenic damage by activating systemic acquired resistance (SAR). It was suggested that $C$. junos exhibited stronger resistance to Phytophthora root rot from the relatively higher LR numbers induced by pathogen infection. In addition, P. trifoliata exhibited the highest root morphological traits than the other citrus plants, regardless of infection with P. parasitica or not. It appeared to show higher resistance to Phytophthora root rot. Considering the relative reduction of root morphological traits under $P$. parasitica, the severity of disease in P.trifoliata was greater than $C$. tangerina, implying an inferior resisted capacity of $P$. trifoliata relative to $C$. junos. In short, in terms of root morphology, the resisted capacity to Phytophthora root rot among these citrus plants was ranked as $C$. junos $>P$. trifoliata $>C$. tangerina $>C$. limon in the decreasing order.

In general, the changes in $\beta$-1,3-glucanase and chitinase activities are obvious synchronicity (Hu et al. 2017). In this work, the variation tendency of both root 


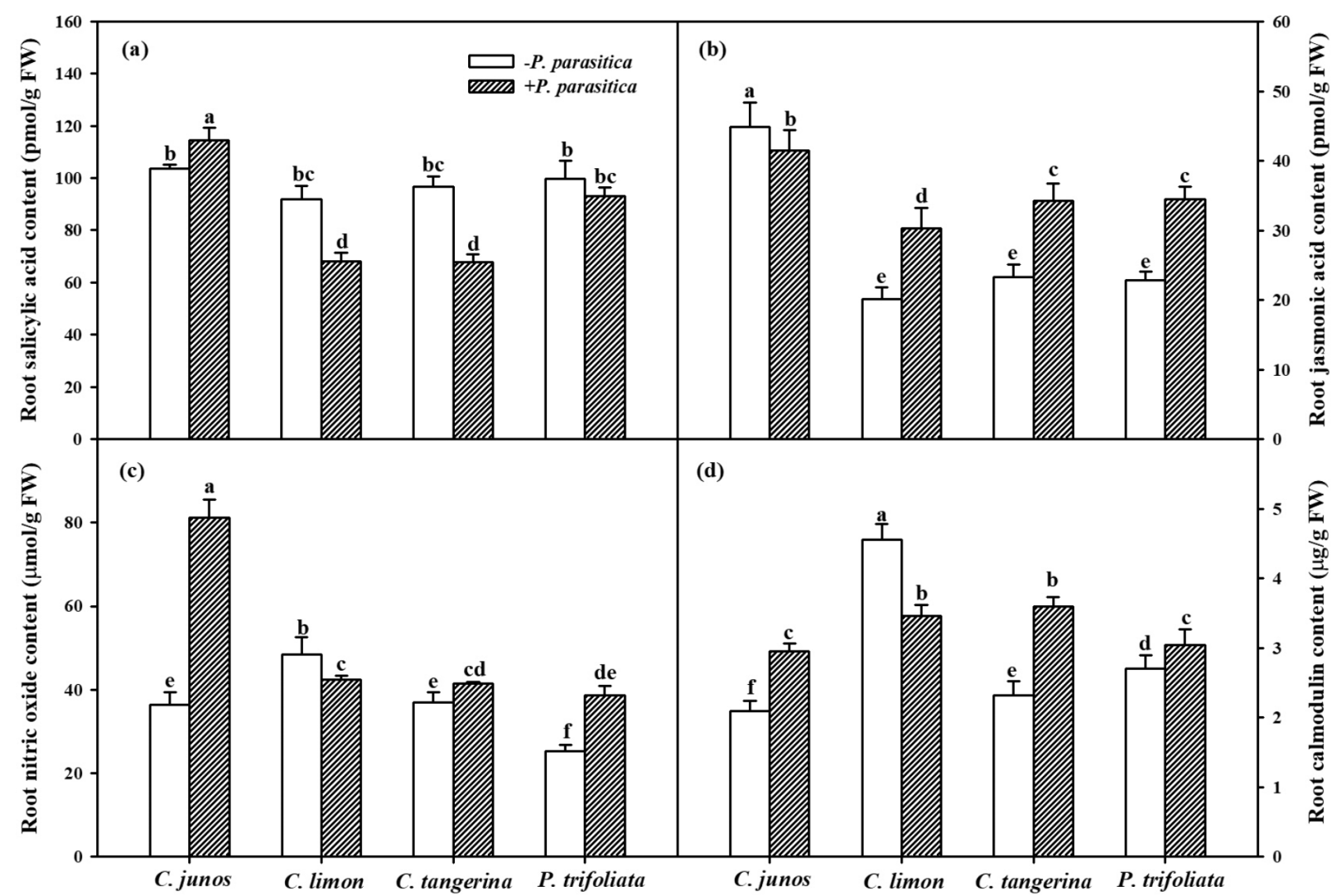

FIGURE 2. Effects of Phytophthora parasitica infection on root salicylic acid (a), jasmonic acid (b), nitric oxide (c) and calmodulin (d) concentrations in Citrus junos, $C$. limon, C. tangerine and Poncirus trifoliata. Data (means $\pm \mathrm{SD}, n=8)$ are significantly different $(p<0.05)$ followed by different letters above the bars. Abbreviation: $-P$. parasitica, non-infection by Phytophthora parasitica; $+P$. parasitica, infection by Phytophthora parasitica

$\beta$-1,3-glucanase and chitinase activities were similar as a whole in different citrus plants infected by $P$. parasitica. In fact, $\beta$-1,3-glucanase and chitinase could hydrolyze the cell wall of pathogenic fungi (Esquerré-Tugayé et al. 2000). In addition, the hydrolytic process of cell wall for pathogen fungi is accompanied with oligose release, which acts as a motivational factor of multiple disease resistance response (Klarzynski et al.2000). In the present work, $P$. parasitica infection considerably increased root $\beta$-1,3-glucanase and chitinase activities in $C$. junos and P. trifoliata, while decreasing that in $C$. tangerina and $C$. limon. Earlier studies confirmed that the expression levels of $G m B G 1$ and $M d C h i$ were higher in disease-resistant varieties than that in susceptible varieties (Li et al. 2003; Zhang et al. 2017). Hence, it could be speculated that $C$. junos and $P$. trifoliata presented higher resistance to Phytophthora root rot than $C$. tangerina and $C$. limon through hydrolyzing the cell wall of $P$. parasitica, especially $C$.junos.

PAL acts as the key enzyme and limiting enzyme in the secondary metabolism pathway of phenypropanoids, exerting the crucial effect on plant disease resistance (Kim \& Hwang 2014). The present study indicated that root PAL activities were increased prominently when these citrus plants were infected by the pathogen. In fact, earlier studies showed the larger and faster increase in PAL activity in resistant cultivars than in susceptible cultivars
(Dixon et al. 2002; Mozzetti et al. 1995; Shiraishi et al. 1995). In this work, $P$. parasitica infection considerably reduced root PAL activities in $C$. tangerina and $C$. limon compared with non-infected seedlings, suggesting that $C$. tangerina and $C$. limon showed lower resistance to $P$. parasitica-induced root rot. In contrast, root PAL activities were highly promoted by $P$. parasitica infection in $C$.junos and $P$. trifoliata, especially $P$. trifoliata, impling that $P$. trifoliata and $C$. junos performed better resistance than $C$. tangerina and $C$. limon.

SA and JA can transfer the signals of wounding, pathogens and herbivores attack to trigger the defense responses in plants (Sanders et al. 2000; Wasternack \& Parthier 1997). The SA signals exhibit a more durable and intense response to pathogen infection (Song et al. 2010). In this work, root SA concentrations increased dramatically in $C$.junos by the pathogen infection, while decreased in the other citrus plants, indicating an oppositely changed trend between root SA concentrations and root JA concentrations by P. parasitica infection in these citrus plants. It is known that SA inhibits JA biosynthesis and defense responses (Glazebrook 2001; Robert-Seilaniantz et al. 2011) and the inhibition is always modulated by transcription factors such as WRKY70, WRKY62, MPK4, MYC2 and NPRl (Bari \& Jones 2009). The present results suggested that $C$. junos responded to pathogen attack primarily by means of 
increasing SA concentration, while $C$. limon, $C$. tangerina and $P$. trifoliata preferred to accumulate root JA contents to defend pathogen infection. As a result, citrus plants possess differently responsive patterns in SA and JA to $P$. parasitica infection.

NO generally takes part in the post-translational modification of proteins involving stress, redox and signaling (Lindermayr et al.2005). The complex of calcium $\left(\mathrm{Ca}^{2+}\right)$ and $\mathrm{CaM}$ can regulate physiological processes in plants (Kim et al. 2009). In our work, apart from C. limon, whose root $\mathrm{NO}$ and $\mathrm{CaM}$ contents reduced dramatically after infection by $P$. parasitica. $P$. parasitica treatment strongly increased root $\mathrm{NO}$ and $\mathrm{CaM}$ concentrations in $C$. junos, $C$. tangerina and $P$. trifoliata. With regard to the relative growth rate, however, $C$. junos was notably higher than $C$. tangerine and $P$. trifoliata, which meant that $C$. junos presented stronger response to the pathogen infection through $\mathrm{NO}$ and $\mathrm{CaM}$ accumulation in roots.

\section{CONCLUSION}

Infection with $P$. parasitica notably reduced the plant growth and root morphology of four citrus plants, whilst the magnitude of reduction was higher in $C$. limon and $C$. tangerina than in $C$. junos and $P$. trifoliata, especially $C$. limon. Besides, activities of PRs were significantly reduced in $C$. limon and $C$. tangerina after $P$. parasitica infection and increased in $C$. junos and P. trifoliata, especially $C$. junos. The pathogen infection also stimulated SA, NO and CaM accumulation in C. junos and JA, NO, CaM accumulation in P. trifoliata. These observations provide the strong evidence that $C$. junos exhibited the highest resistance to Phytophthora-induced root rot, followed by $P$. trifoliata, $C$.tangerina and $C$. limon in decreasing order of the resistance.

\section{ACKNOWLEDGEMENTS}

This study was supported by the Plan in Scientific and Technological Innovation Team of Outstanding Young Scientist, Hubei Provincial Department of Education (T201604). It was also supported by the Long-Term Development Plan of UHK.

\section{REFERENCES}

Bari, R. \& Jones, J.D. 2009. Role of plant hormones in plant defence responses. Plant Molecular Biology 69(4): 473-488.

Bonnet, J., Danan, S., Boudet, C., Barchi, L., Sage-Palloix, A. \& Caromel, B. 2007. Are the polygenic architectures of resistance of Phytophthora capsici and P. parasitica independent in pepper? Theoreticao \& Appied Genetic 115(2): 253-264.

Davis, R.M. \& Menge, J.A. 1980. Influence of Glomus fasciculatus and soil phosphorus on Phytophthora root rot of citrus. Phytopathology 70(5): 447-452.

Dixon, R.A., Achnine, L., Kota, P., Liu, C.J., Reddy, M.S. \& Wang, L. 2002. The phenylpropanoid pathway and plant defence-a genomics perspective. Molecular Plant Pathology 3(5): 371-390.
Esquerré-Tugayé, M.T., Boudart, G. \& Dumas, B. 2000. Cell wall degrading enzymes, inhibitory proteins, and oligosaccharides participate in the molecular dialogue between plants and pathogens. Plant Physiology and Biochemistry 38(1): 157163.

Glazebrook, J. 2001. Genes controlling expression of defense responses in Arabidopsis-2001 status. Current Opinion in Plant Biology 4(4): 301-308.

Gray, M.A., Hao, W., Forster, H. \& Adaskaveg, J.E. 2017. Effect of new Oomycete-specific fungicides on tree health, fruit yields and Phytophthora root rot of citrus. Phytopathology 107: 186.

Hu, N., Tu, X.R., Li, K.T., Ding, H., Li, H., Zhang, H.W., Tu, G.Q. \& Huang, L. 2017. Changes in protein content and chitinase and $\beta$-1,3-glucanase activities of rice with blast resistance induced by Ag-antibiotic 702. Plant Diseases and Pests 8(4): 33-36.

Kim,D.S. \& Hwang, B.K. 2014. An important role of the pepper phenylalanine ammonia-lyase gene (PAL1) in salicylic aciddependent signalling of the defence response to microbial pathogens. Journal of Experimental Botany 65(9): 22952306.

Kim, M.C., Chung, W.S., Yun, D.J. \& Cho, M.J. 2009. Calcium and calmodulin-mediated regulation of gene expression in plants. Molecular Plant 2(1): 13-21.

Klarzynski, O., Plesse, B. \& Joubert, J.M. 2000. Linear $\beta$-1,3glucans are elicitors of defense responses in tobacco. Plant Physiology 124: 1027-1037.

Latijnhouwers, M., De Wit, P.J. \& Govers, F. 2003. Oomycetes and fungi: Similar weaponry to attack plants. Trends in Microbiology 11(10): 462-469.

Li, Y.Z., Zheng, X.H., Tang, H.L., Zhu, J.W. \& Yang, J.M. 2003. Increase of $\beta$-1,3-glucanase and chitinase activities in cotton callus cells treated by salicylic acid and toxin of Verticillium dahliae. Acta Botanica Sinica 45(7): 802-808.

Lindermayr, C., Saalbach, G. \& Durner, J. 2005. Proteomic identification of S-nitrosylated proteins in Arabidopsis. Plant Physiology 137(3): 921-930.

Liu, J.J. \& Yin, G.Y. 1993. Study on the root rot and yellow leaf disease of citrus in Jiangsu and Hubei provinces. Journal of Nanjing Agricultural University 16(1): 38-44 (in Chinese with English abstract).

Mozzetti, C., Ferraris, L., Tamietti, G. \& Matta,A. 1995. Variation in enzyme activities in leaves and cell suspensions as markers of incompatibility in different Phytophthora-pepper interactions. Physiological and Molecular Plant Pathology 46(2): 95-107.

Queiroz, B.P.V. \& Melo, I.S. 2006. Antagonism of Serratia marcescens towards Phytophthora parasitica and its effects in promoting the growth of citrus. Brazilian Journal of Microbiology 37(4): 448-450.

Robert-Seilaniantz, A., Grant, M. \& Jones, J.D. 2011. Hormone crosstalk in plant disease and defense: More than just jasmonate-salicylate antagonism. Annual Review of Phytopathology 49: 317-343.

Sanders, P.M., Lee, P.Y., Biesgen, C., Boone, J.D., Beals, T.P., Weiler, E.W. \& Goldberg, R.B. 2000. The Arabidopsis DELAYED DEHISCENCE1 gene encodes an enzyme in the jasmonic acid synthesis pathway. The Plant Cell 12(7): 1041-1061.

Shiraishi, T., Yamada, T., Nicholson, R.L. \& Kunoh, H. 1995. Phenylalanine ammonia-lyase in barley: Activity enhancement in response to Erysiphe graminis f. sp. hordei 
(race 1) a pathogen, and Erysiphe pisi, a nonpathogen. Physiological and Molecular Plant Pathology 46(2): 153162.

Song, Y.Y.,Zeng, R.S., Xu, J.F., Li, J., Shen, X. \& Yihdego, W.G. 2010. Interplant communication of tomato plants through underground common mycorrhizal networks. PloS ONE 5(10): e13324.

Vallad, G.E. \& Goodman, R.M. 2004. Systemic acquired resistance and induced systemic resistance in conventional agriculture. Crop Science 44(6): 1920-1934.

Wasternack, C. \& Parthier, B. 1997. Jasmonate-signalled plant gene expression. Trends in Plant Science 2(8): 302-307.

Yan, H.X., Zhong, Y., Jiang, B., Zhou, B.R., Wu, B . \& Zhong, GY. 2017. Guanggan (Citrus reticulata) shows strong resistance to Phytophthora nicotianae. Scientia Horticulturae 228: 141-149.

Zhang, L., Wei, L., Tang, X.F., Wang, W.W., Yu, Z.Y. \& Liu, L.J. 2017. Bioinformatics analysis of soybean $\beta$-1,3-glucanase $(G m B G 1)$ and its homologous proteins. Genomics and Applied Biology 36(3): 1035-1042.

Zhou, C.H. 1999. Resistance identification of citrus somatic cell hybrid to Phytophthora parasitica and study of Phytophthora parasitica toxin. Doctoral dissertation, Wuhan: Huazhong Agricultural University (Unpublished).
Li Tian \& Qiang-Sheng Wu* College of Horticulture and Gardening Yangtze University

Jingzhou, Hubei 434025

China

Qiang-Sheng $\mathrm{Wu}^{*}$ \& Kamil Kuča

Department of Chemistry, Faculty of Science

University of Hradec Kralove

Hradec Kralove 50003

Czech Republic

Mohammed Mahabubur Rahman

Brix' N Berries

Leduc, Alberta

Canada

*Corresponding author; email: wuqiangsh@163.com

Received: 2 March 2018

Accepted: 4 April 2018 